\title{
Perception of Society and Democracy in Ottoman Liberal and Socialist Thought
}

\author{
Atila Doğan*, Haluk Alkan*
}

\begin{abstract}
The Second Constitutional Monarchy (1908-1918) marked the beginning of a period during which various thoughts and movements that had been united in their opposition to Abdulhamid II become disunited, organized independently of each other, and were able to express themselves. This era was not only instrumental in shaping Ottoman liberal and socialist thought but also constituted the dynamics of the events that would set the course of such thoughts in the Republican era. This study provides a comparative analysis of how liberal and socialist movements in the late Ottoman Empire perceived society and democracy in the aftermath of the Second Constitutional Monarchy. It first examines the views of the two leading groups of Ottoman liberal thought, namely, Ulum-u iktisadiye ve Içtimaiye Mecmuası (The Journal of Sciences of Economics and Society) and Teşebbüs-i Şahsi ve Adem-i Merkeziyet Cemiyeti (The Private Enterprise and Decentralization Society). Second, the views of Ottoman socialists are addressed with reference to the groups that constituted the background of the Ottoman Socialist Party and the Turkish Communist Party. The study ends with a comparative discussion of the conclusions reached.
\end{abstract}

Keywords: Ottoman, society, democracy, liberalism, socialism.

Öz: II. Meşrutiyet Osmanlı Devletinde Abdülhamit karşıtlığı çerçevesinde bir araya gelmiş çeşitli düşünce ve akımların birbirlerinden özerkleşerek örgütlendikleri ve kendilerini ifade edebildikleri bir dönemin başlangıcını oluşturmuştur. Bu dönem Osmanlı liberal ve sosyalist düşüncesinin şekillenmesinde belirleyici olduğu gibi Cumhuriyet döneminde bu düşüncelerin seyrini belirleyen olayların da dinamiğini oluşturmuştur. Çalışma II. Meşrutiyet sonrasında Liberal ve Sosyalist akımların Osmanlı Devletindeki yansımaları olan kişi ve kuruluşların toplum ve demokrasi algılamasını karşılaştırmalı bir biçimde incelemeyi amaçlamaktadır. Çalışmada öncelikle Osmanlı liberal düşüncesinde belirleyici olan iki grubun, Ulum-u İktisadiye ve İçtimaiye Mecmuası çevresi ve Teşebbüs-i Şahsi ve Adem-i Merkeziyet Cemiyeti'nin toplum ve demokrasi görüşleri incelenmektedir. İkinci olarak Osmanlı Sosyalist Fırkası ve Türkiye Komünist Partisi'nin arka planını oluşturan gruplaşmalar çerçevesinde Osmanlı sosyalistlerinin aynı konulardaki görüşleri ele alınmaktadır. Çalışmanın sonunda ulaşılan sonuçlar karşılaştırmalı olarak tartışılmaktadır.

Anahtar kelimeler: Osmanlı, toplum, demokrasi, liberalizm, sosyalizm.

* Assoc. Prof. Dr., Karadeniz Technical University, Faculty of Economics and Administrative Science, Department of Public Administration.

Correspondence: atiladogan68@hotmail.com. Address: Karadeniz Teknik Üniversitesi, Iktisadi ve Idari Bilimler Fakültesi, 61080 Trabzon/Türkiye.

** Prof. Dr., Istanbul University, Faculty of Economics, Department of Political Sciences and International Relations Correspondence: halukalkan@hotmail.com, İstanbul Üniversitesi 34452 Beyazı//Fatih-Istanbul/ Türkiye.

D0l: dx.doi.org/10.12658/human.society.5.10.M0153

İnsan ve Toplum, 5 (10), 2016 


\section{Introduction}

The Second Constitutional Monarchy witnessed the beginning of several major developments that would influence Ottoman political thought in the succeeding periods. During this era, several movements that emerged along with the Ottoman modernization process were able to express themselves freely and strove to spread their thoughts through journals and organizations. Different movements of thought also started to criticize each other. Several movements that were united in opposition to Abdulhamid II before the Constitutionalist Monarchy started, to disclose the intellectual grounds of their thoughts and expressing themselves more independently against rival movements (Hanioğlu, 2001, p. 314; Seyrek, 2010, p. 1441). Most notably, discussions over the intellectual grounds for and the way to achieve national sovereignty and democracy involved became rather extensive among Ottoman intellectuals.

This study offers a comparative analysis of how seeks to analyze comparatively how liberal and socialist individuals and institutions perceived society and democracy in the post- Second Constitutional Monarchy period. It first examines the views on held by the two leading groups of Ottoman liberal thought, namely, Ulum-u İktisadiye ve Içtimaiye Mecmuası (UiiM) and the Teşebbüs-i Şahsi ve Adem-i Merkeziyet Cemiyeti. Second, the views of Ottoman socialists are addressed in terms of the groups that constituted the background of the Ottoman Socialist Party and the Turkish Communist Party. The views of non-Muslim Ottoman socialists on the same subjects are not included because their influence on their Muslim peers was limited due to the nationalist feelings that increased after the Balkan Wars.' Ultimately, the findings are compared at the end of the study.

This work represents considerable contribution to the "history of thought" literature by providing an analytical approach through which one can compare socialist perceptions of society and democracy on the one hand, and two liberal currents represented by UiiM and Prens Sabahaddin.

\section{Two Sides of Ottoman Liberalism: UiiM and Teşebbüs-i Şahsi ve Adem-i Merkeziyet Cemiyeti}

Before examining how democracy was perceived in Ottoman liberal thought, one must address certain differences among the various liberals and their intellectual backgrounds. In this connection, there are two remarkable trends: UiïM and Teşebbüs-i Şahsi ve Adem-i Merkeziyet Cemiyeti. UiiM is the first philosophical liberal thought journal to show, inter alia, how the West influenced Ottoman liberal thought (Ülken, 1992, pp. 159-161; Doğan, 2006, pp. 174-178; Çavdar, 1992, pp. 141-144; Karaman, 2004, pp. 65-87). It was initially published in 1908 after the Second Constitutional Monarchy, allowed Parliament to re-convene and various intellectual trends and political movements began to organize and work for change. The journal's founders, namely, Ahmed Şuayb (1876-1910), Mehmed Cavid (18751926) and Riza Tevfik (1869-1949) interpreted economic liberalism in the light of August Comte's positivism, Herbert Spencer's social evolutionist thought and with a selective political understanding (Doğan, 2005, p. 81). 
This is reflected clearly in the first volume's two-part program. The first part which advocates economic liberalism. Points out that political discussions and arguments related to land were replaced by fierce economic conflict in the recent era of the human history and that empires shaped their relationships accordingly. As a result, merchant- and artisanbased empires resorted to effective methods to dominate those economically underdeveloped countries that still relied upon the conventions of periods dominated by lethargy and inertia. From this point of view, the founders stated that one of the journal's top priorities was to observe those methods and explain the basis of development.

They contended that the recent considerable improvements made by Comte and Pierre Guillaume Frédéric Le Play's sociological theories enabled one to respond to any issue and problem with a meticulous attention. These theories completely changed human knowledge in the fields of philosophy, history, law, ethics, civility and art; opened up a completely new horizon; and presented humanity with a new thought system (Ahmet Şuayb, et. al., 1324, p. 9). Thus, they declared that the science of sociology would provide a key method to formulate a new understanding of society and politics and shape economic liberalism.

The Teşebbüs-i Şahsi ve Adem-i Merkeziyet Cemiyeti, founded in 1906 within the framework of Ottoman liberal thought, and its journal Terakki, have a different understanding of society and democracy. Established by Prince Sabahaddin and including such, figures as Dr. Nihat Reşat, Dr. Sabri, Hüseyin Siret, Dr. Rıfat, Ahmet Fazlı, and Hüseyin Tosun, this society's stated purpose was "spreading sociology among citizens and making translations to that end." This goal, which was published in the first volume of its monthly journal was in concordance with the program of Uiim (Akşin, 1972, p. 543).

The primary difference of between these two groups vas the latter's discourse, which emphasized political purposes rather than theory. The program published in Şurayi Ümmet on July 27, 1906, called for strengthening local administrations (Akşin, 1972, p. 544). Sabahaddin, a leading advocate of this trend, followed the Science Sociale school, a heterodox branch of the followers of Le Play in France. He became a friend of its leader, Edmond Demolins, in Paris and decided to adapt his views to Ottoman society by interpretating them in a way that put individual at the center (Bakırezer, 2005, pp. 141-142). His thought was grounded in creating a comprehensive development strategy by adapting Demolins' classification of societies to the development of Western communities and the underdevelopment of the Ottoman society (Helvacl, 2007, pp. 37-38). An opponent of Abdulhamid's government, both because of his ideas and for family-related reasons, he sided with the Young Turk opposition and advocated socio-political reforms that favored establihing a social structure based on a decentralized state and individual entrepreneurship. This approach may account for his life-long career in politics for as a man of action whose thoughts and activities directly influenced politics. He worked hard to link theory and political practice and to develop a political methodology.

\section{Two Liberal Trends with Different Views on Social Development}

UiiM authors asserted that social life and the science of sociology that examines it can be understood by presuming the existence of a set of basic guiding rules. Social life and structures can be explained by relating them to biological life and organs, for people are not 
decisive actors; rather, they dependent beings who act in accord with guidance of social laws (Alkan \& Doğan, 2010, p. 71). Social ability, the basic guiding element describes the core trends that cause them to come together and establish a union. Its function in social life is similar to that of the human nervous system to establish and regulate the social unit's functional similarity and its participation in the organism.

As with living organisms, the nature and degree of the common relationship among society's units determine the level of social ability. In other words, social ability develops to the extent that social relations increase and differentiate. Social units that are repeated again and again and therefore subjected to the same rules gradually become inclined to constitute a harmonious organization. The concept of social ability covers the entirety of the functions and common relations of the societies in which the living creatures dwell; constitutes the outcome, integrity, and accumulation of social relations; and is proportional to a particular society's level of development. An opinion that is above a society's level of development cannot emerge. If it does emerges, it gets reaction and cannot find any change of implementation (Bedi Nuri, 1325, pp. 322-331).

Social groups and individuals are also differentiate themselves due to various external factors. A living organism can only feel the effects on its vitality created by different factors. Thus, the basic cause that leads to differentiation is external effect. Changes in environmental conditions constitute the dynamics of social development. Development is predisposed to differentiation, which, in return, shapes social ability. What determines social structure, ethics, and feelings is again social ability. Spirituality and ethics do not shape the moods of people. Interdependency, interrelations, and division of labor are essential for social development as is the case with development in the world of living creatures. That the organism's stages of nutrition, reproduction, and growth create the necessity for such processes cannot be denied. This is also true for societies. Authors reduce social science to a social development process, consider social life as an organism that is led toward foreseeable targets, and base the entire framework on a materialistic foundation.

Asaf Nefi opines that social development is a consequence of the ongoing struggle for life within the world of plants, animals, and human societies at any level. The struggle for life is a fact which is true for animals, plants and societies at any level. Each creature has to struggle with its fellow creatures and its surrounding environment. He refers particularly to Bufon, Darwin, and Malthus, all of whom described this truth scientifically and applied it to social life. Without this struggle, civilization would neither arise nor progress. The struggle in which people and societies engage to preserve their own positions allow the society in question to move toward civilization. In this framework, four factors affect a society's historical development: the struggle (1) for life in terms of the present and future generation's welfare, (2) for a better position (i.e., personal competition), (3) among classes to attain a more privileged position, and (4) among the distinguished classes themselves or with other social groups to acquire more benefits. These four core realities are indeed types of struggle for life and the "winners" will outclass all others in intellectual development (Asaf Nefi, 1325, pp. 455-460).

According to Asaf Nefi, the inequality to which social development gives rise increasingly results in the formation of two unequal groups: (1) a farsighted and distinguished minority, (2) and the ignorant majority (ekseriyet zulmet-i ama) thus holds the power of pressure, however, has a limited ability to distinguish reality" (Asaf Nefi, 1325, pp. 472-473). 
The dilemma of a narrow-minded majority against a distinguished minority is a key element in understanding how Ottoman liberals see democracy. According to Riza Tevfik, social development moves from equality to differentiation. Therefore, equality assumes different meanings according to the level of social development. He mentions, in detail, the similarities of people in black communities, but also of a differentiation between types of people in civilized nations. According to him:

If we observe and study the skull of the human kind, we see that the head of all black people are similar to each other. However, if we were to collect the skulls from the graveyard of a civilized nation, we would see significant differences in terms of shape and size. (Riza Tevfik, 1326a, p. 552)

Riza Tevfik criticizes the social contract theory of Hobbes and Rousseau on the grounds that it defends the view that a primitive society establishes its government with a contract and denies the reality of social development. He says the government was born out of the need to dispense justice among individuals (1326a, pp. 361-363), "The Government was born from cruelty and violation" (1326a, p. 363). Likewise, Ahmed Şuayb states that those approaches that emphasized equality and considered human nature to be inherently good gave rise to an incorrect evaluation of the political and social events at his age. According to Ahmed Şuayb, although the thought that all evils come from society dominated in Europe, criticisms of such thinkers as Hegel, Straus, Mill, Spencer, Comte, and Renan helped people question this view. Human nature is bound to imbalance. "Human beings are insane as they are innately ill" (Ahmet Şuayb, 1324, p. 58). In short, Rousseau's belief in the inherent goodness of human nature is just a dream. Therefore, a state's government depends upon social development processes and the social, as opposed to the individual. Political authority is a consequence of inequality, not of the quest for equality.

Human progress is shaped by the struggle between two forces: the community's conservative tendencies. Conservatives generally try to subjugate those who are dissatisfied with their society's current rate of progress and thus try to exceed it. In particular, autocracy that depends upon people is the most dangerous type of autocracy. "It is therefore implemented based on the authorization and consent of the public. Any step towards development is considered as an infringement of common law, and constitutes a pretext to apply pressure on supporters of development. Yet, there lies the real threat" (Riza Tevfik, 1325b, p. 191). "If an ordinary man" observes that many other people share his feelings, then he considers that situation as the only evidence. Conservatives look at the majority (Rıza Tevfik, 1325b, p. 200). The opinions that dominated the UiiM side of Ottoman liberal thought are shaped by their description of political power within the framework of the laws applicable to society and the concept of social development, their support for progressive change as opposed to revolutionary political movements and sudden political changes, and their desire for distinguished leadership. This point of view will lead them to criticize democracy because it is based on egalitarian approaches.

Sabahaddin does not focus on the theoretical dimension of social development thought as much as Uiim group does. However, one can see hints of how he views development in his articles. For example, he writes that those who best adapt to natural laws are those who can transfer their lives, both biologically and socially, to their descendants, which is the 
source of power. Every society has to see this truth in social life. Those who fail to see this truth will have to go through a painful process until they comprehend (Alkan, 2007, p. 50). The scientific method has helped people progress at a never-before-seen rate of speed. As the same method, though limited, is applied to social events, it has recently been realized that similar results can be achieved. Thus, when identifying a social movement's path and the method it will follow, one must benefit from the "observation methods and experience" (Alkan, 2007, p. 53).

Sabahaddin, as opposed to the UiIM group, considers the relationship between society and progress from a very positive point of view, for "the idea of progress which civilizes the wild arises with a freedom that disregards any control other than natural social balance" (Alkan, 2007, p. 59). As a result, his view of his own society positive. In fact, he states that Turkish peasants possess a pure character open to progress so that when the obstacles confronting them are removed, they can create the social dynamics for progress.

Yes, the real Turk who works day and night without a moment of peace, that peasant who pays the same tax every year repeatedly without taking into account the blood tax, who is uninterruptedly exposed to maltreatment and pressure of his own government and to the dominance and humiliation of the European public opinion. That innocent peasant is in fact a serious and honest servant of civilization. The children of that peasant who learn the new sciences at the desks of schools and universities and prepare a future of freedom and a future of honorable humanity for them deserve admiration and friendship. (Alkan, 2007, p. 116) "... we should win the peasant to our cause before he loses his innate innocence and establish active and successive centers to win him." (Alkan, 2007, p. 249)

Sabahaddin was strongly influenced by some social responses, -particularly those in Erzurum- which caused Istanbul to take a step back in Anatolian cities under Abdulhamid II. These events strengthened his opinion that the Anatolian people could be the driving force of a progress through good organization. Sabahaddin was of the opinion that a process that could close the gap between European States and the Ottoman State quickly could be started (Alkan, 2007, pp. 210-211). Thus he considered revolution to be a positive idea and cited the French Revolution as a brilliant example of how to establish a pro-liberty government, the outcome of a progress initiated by the civilized society (Alkan, 2007, p. 64). In his opinion, revolution is the key of a change that would clear the way for the society under the guidance of organization and education. In this sense, the role of the elite is not to guide progressive change, but to overcome the prevailing problems by supporting the Ottoman society with the necessary instruments.

The prince further states that human beings belong to two types of formations: communistic and particularistic. A shift between these formations can only be possible if the methods of social science are employed. Demolins states that the communistic formation is characterized by a tendency to rely not upon oneself but upon the community, namely, the group, family, tribe, clan, public powers, and so on, and therefore is dominated by these groups. The populations of the East are the most striking representatives of this type, for their centralist structure is foreign to democracy and tend to have large bureaucracies. According to the law of development, the communistic formation preceded the particularistic formation. In Demolins' words, the particularistic social formation is characterized by a tendency 
to rely upon oneself. These abilities emerge and progress in social life. The Scandinavian and Anglo- Saxon countries are the most striking representatives of this type (Alkan, 2007, p. 517-518). Any democratic society based on decentralization becomes stronger. As long as the Ottoman Empire's social structure remained dependent upon the center, it would continue to be oppressive and unable to develop. In sum, changing the centralist structure was a top priority (Alkan, 2007, p. 194).

Moreover, he believes in a type of social development that is materially based on the AngloSaxon experience, meaning that development is subject to the principles of the laws of nature. After establishing a connection between the biological and physical world and the social event, he argues that these phenomena can be explained via the same laws and that, in time, sociology will solve social problems like science does. Yet he does not see society as the only source of underdevelopment, for the real problem is the oppressive centralism that prevents a shift to a particularistic formation and consequently the development of individual entrepreneurship. Based on his positive view of society, as opposed to that UiiM authors, he writes that after the overthrow of an oppressive regime, even by a revolution, if necessary, will usher in an era of development that will quickly close the gap between the Ottoman community and the West. This is the intellectual background that shapes the prince's view of politics and democracy.

\section{Ottoman Liberals and Democracy}

Ottoman liberal thought accommodates two tendencies toward democracy that are in line with the two school of social thought addressed above. The Uiim group sees democracy as a casual element for development, whereas Prince Sabahaddin and his fellows view it as a purpose that needs to be attained.

Ahmet Şuayb, an UiiM author, describes democracy as the autocracy of the people, and, in that sense, assert that it cannot be the opposite of autocracy. According to him, democracy is an understanding of government that has developed in line with the corruption found in modern society due to the now-overwhelming importance of economic interests and money. The basic tendency of human nature is to become rich. In the past, this tendency was limited by those religious and social rules that tried to discourage it. But in our own time everyone wants a share, in the belief that they deserve it, and thus struggle whit those who would deny it to them (at least in their opinion). When they fail to achieve this goal, "they get mad and revolt against the society due to that deprivation" (Ahmet Şuayb, 1325, p. 290). Democracy has legitimized the superiority and reign of money as a natural consequence of social development. While democracy expresses the thought of human equality in theory, it allows a money-dependent autocracy to prevail. As people do not have the knowledge and tools to recognize and elect those efficient people who will benefit them, the only measure of people is money. Democracy gives rise to a distinguished class: plutocracy. This is the natural consequence of the increased power acquired by industry and trade, for a democratic structure, opens the way for those ambitions people who want to wealth (Ahmet Şuayb, 1325, p. 311). 
Rıza Tevfik states that the phenomenon of liberty must not be considered as a right that can be granted, but a recognition of the individual liberty of those members of the elite who can actually develop a society, regardless of how it is governed. He argues that granting this right to ordinary people, the majority, is not important on the ground the elite can use this right effectively only if they are immune to the demands of the majority. Concordantly, he denies the possibility that a system founded upon popular representation and majority rule can, in its own right, foster liberty (Rıza Tevfik, 1325a, p. 234). Rıza Tevfik goes so far as to accuse democracy of taking the easy way out by assuming that the majority's opinion is correct and grounding its governing method on that assumption. In fact, he writes that parliamentary democracy's greatest mistake is the mistaken claim that such a government can make correct decisions at any time and on any issue (Rıza Tevfik, 1326c, p. 745).

Just as leaders and dynasties were deemed holy and their laws were obeyed, this same holiness is ascribed to the Parliament in a parliamentary system (Riza Tevfik, 1326c, p. 747). As the qualifications of the governing minority change in line with social change, it is unreasonable to consider democracy a system, for any individual, whether good or bad, clever or foolish, qualified or unqualified has the authority to manage affairs and has one vote (Riza Tevfik, 1326b, pp. 614-615). To him, in line with the development process in time, a distinguished group of professional politicians will arise to execute the correct policies. Just as people consult doctor when they are ill or a lawyer when their rights are violated, they should do the same thing in the political sphere. When individuals "achieve the wisdom and education" to notice this, the classification of politics as a profession will become possible (Rıza Tevfik, 1326b, p. 620).

The UiiM group tends to oppose any movement grounded in thoughts of equality because, they argue, such movements obscure reality by ignoring the differentiation and inequality needed to develop and progress. They therefore deny both social contact theory and the natural law doctrine, asserting that primitive people and wild communities cannot establish a contract that and law, which is the product of social development (i.e., a modern community), cannot determine common rules that will be applicable to both communities. Not only does the idea of having an equal vote bring forward the demands of narrow-minded majorities and thereby prevent the elite from playing a guiding role, but classifying this as a right results in short-lived and faulty decisions that engender social conflict, causes revolutionary approaches to gain strength, and leads to social corruption.

Unlike Uiim authors, Sabahaddin thinks that a nationwide organization that secures the people's support can fight an oppressive regime. For that purpose, centers should be established in Anatolia to win over the peasants before they lose their natural innocence, and similar organizations must be establish to over win the good people among the rich lowlevel officials and officers (Alkan, 2007, pp. 249-250). Such organization would constitute the substructure for the revolution and the establishment of a legitimate post-revolution government. However, such a transition from personal power to a parliamentary system is not enough to achieve this goal. The prince also remains skeptical of the parliamentary system, like UiiM group- not- because he fears the pressure of the conservative majority, but because the representatives might act beyond the control of the people. In other words, he does not defend a Parliament that is limited to the elite, but one that cooperates with 
a decentralized government structure (Alkan, 2007, pp. 244-245). For these reasons, the nation should not assign their rights to anybody; rather, they should maintain the right to inspect the power they assign to the central government via representatives and to manage local affairs through the reliable people they elect (Alkan, 2007, p. 245). This type of management depends upon local government, as opposed to receiving orders given by the center, for it requires locally established committees to be granted the necessary authority and instruments to carry out this task. Thus these managers will be people who are familiar with the locality's specific characteristics instead of "nomadic officials". The people must also participate through educated people who hold a respected position in private life and are particularly engaged in production activities (Alkan, 2007, pp. 409-410).

He also makes a series of recommendations for how to operate a decentralized system so that it will help strengthening individual initiative and will liberate the people from their traditional dependency on the center. Among these are devising and then implement legal and administrative reforms that make it relatively easy to turn public property into personal property, empower local administration to undertake civil works and manage public enterprises, allocat autonomous budgets to the provinces, allow local administrations to borrow funds, and improve their tax collection powers. All these reforms must be supported by an educational system that improves one's personal identity (Alkan, 2007, pp. 410-413).

In addition, he also maintains that Parliament alone cannot develop democracy. Given that a Parliament can only function according to the level of the people's conscience and understanding, it can produce either positive or negative results (Alkan, 2007, p. 518). In other words, democracy to take root in a given country, it must be supported by a decentralized administration and a sophisticated education system that produces entrepreneurs.

Clearly, this understanding of democracy is not an elitist understanding that focuses on the center, but rather an idea of social transformation that favors cooperation between the center and local elite within the framework of a nationwide organization. Instead of fearing the majority, democracy can be defended via a system in which the local elite's efficiency is increased through legally supported local administrations, and hence any deviation toward centralism can be prevented. Sabahaddin argues that Ottoman society will welcome that system and may be the driving force of development.

\section{Ottoman Socialists: Ottoman Socialist Party and Turkish Communist Party Tradition}

Ottoman socialists can be categorized into two tendencies. The first one is the movement that established the Ottoman Socialist Party during September 1326 (1910), the empire's first socialist party, was represented by Hüseyin Hilmi (1855-1922) and his fellows. ${ }^{2}$ These members published the first issue of their journal, İştirak, on February 26, 1910, to disseminate their views. In an attempt to prevent its closure by the military rulers of that period, namely, Divan-i Harbi Örfi, they published other journals: Sosyalist, Insaniyet, and

2 Among the founders of the party were Namık Hasan, owner of Sosyalist; Pertev Tevfik, owner of Muahede; İbnüh Tahir, İsmail Faik, owner of İnsaniyet. See Tunaya 1984, p. 247. 
Medeniyet. Some of the journal's other authors were Vahan Vakfi, and Bedik (Mustafa Nuri). Işstirak resumed publication under the same name in 1912 (Tunçay, 1978, pp 37-60). Hüseyin Hilmi founded a second party, the Turkish Socialist Party, in 1919 during the period of truce after The First World War (Tunçay, 1978, p. 83). Hüseyin Hilmi was influenced by Baha Tevfik (1881-1914), an advocate of materialistic thought in the last period of the Ottoman Empire. This figure argued that there was a tight link between materialistic philosophy and science and based his views on an understanding of evolutionary progress (Güzel, 2008, p. 49). Although Hüseyin Hilmi was nourished with these opinions, he had a very pragmatic tendency when it came to politics and tried to cooperate with various segments, including the Islamists. This caused problems with his fellows, other socialists, and the contemporaneous administration. Although some say that he cannot be considered a real socialist ${ }^{3}$, he nevertheless occupies an important place in Ottoman socialist thought. ${ }^{4}$

The second tendency, as narrated by Murat Belge, intellectuals who came from the Union and Progress movement, had a nationalist background, gradually began to differ with the Union and Progress administration, and became aware of and adopted socialist thought for various reasons (2008, p. 28). Dr. Hasan Rıza, Dr. Ethem Nejat, Mustafa Suphi, Dr. Şefik Hüsnü can be listed among the figures of this tendency. Although they followed different ways, they all shared the common trait of being very educated and laying the foundations of the Turkish Communist Party, and hence of the country's Marxist tradition. Their other common trait was their a political inclination to get close to the Ankara government.

Hasan Riza, a former member of the Union and Progress movement, founded the Socialist Democrat Party in 1918. Cemil Arif and Ziynetullah Nuşirevan (Zenon) ${ }^{5}$ were the party's other important figures. Later on, Ziynetullah Nuşirevan helped inaugurate the Turkish People's Socialist Party, which was founded with Ankara's approval in 1920 (Tunçay, 1978, p. 185). Ethem Nejat, another member of the Turkish Nationalist tradition -Union and Progress movement, gravitated toward leftist thought after visiting Germany in 1918 (Altın, 2008, p. 74). Yet, he continued to defend the social Darwinist evolution theory in his studies (Tunçay, 1978, pp. 212-214). He and Vedat Nedim (Tör) were among the authors of the Kurtuluş journal, published on May 1, 1919, in Berlin. These people then established the Turkish Workers and Peasants Socialist Party on September 22, 1919, along Şefik Hüsnü and Mustafa Suphi. This group endeavored to cooperate with Ankara, as stated above, but ultimately failed to do so (Gürel \& Nacar, 2008, p. 122). Ethem Nejat and Mustafa Suphi were killed off-shore Trabzon on December 29, 1921, along with some of their fellows (Altın, 2008, p. 75). The Party was dissolved in 1924 and some of its founders joined the single party bureaucracy (Tunaya, 1986, p. 499). Some members of thise group later participated in the Kadro journal which was initially published in 1932 and had a Kemalist-leftist tendency (Güzel, 2008, p. 55).

5 Ze Nun are the initials of the name of Ziynetullah Nuşirevan in Arabic alphabet, and these letters which were thought to be a name by most people were also read as "Zenon" (Kurtuluş 1975, p. 231). 


\section{The Views of Ottoman Socialists about Society and Equality}

Ottoman socialist thought places development at the heart of its approach to society, as do the liberals. The socialist also voice opinions similar to those of liberals by saying that social development is a key concept in understanding social life. However, their view of the development process and its consequences differ. According to Vahan Vasfi, Darwin's evolutionary theory, which is the glory of $19^{\text {th }}$ century, shows us that all change in social life is the product of progressive centuries. The current structure of society is not the product of a few people's thoughts, but the outcome of a centuries-long evolution. Socialism is a maturation, a theory about the evolution of humanity based upon the belief that progressing from animalism to humanity, from slavery to freedom, involves the necessary passing through of several phases and defeating nature. Socialism is a new stage, a new era of civilization determined by the economic conditions that appear during this progress (Vahan Vasfi, 1326, p. 4). Science reveals the absolute truth: The law of struggling for life, which occurs in all aspects of life, reigns over communities, nations, and governments in a natural way and leads to bloody conflicts that determines who will and will not survive. The principle that "he who wins will rule" is just as true today as it was in the past (Ferda, 1325, pp. 34-35).

Socialist authors also diverge from the liberals in terms of the development process and its consequences. The author of "What is Socialism" published in iştirak, pointed out that liberals contend that society is ruled by unchangeable natural laws and therefore, defend the claim that intellectuals must discover the principal laws of nature and cooperate with any government that tries to adapt the society to them. According to them, observing natural laws do not block freedom, but help a society develop toward freedom. Given that those who work for their own benefit will create out of contrast, it is essential to defend and preserve free enterprise, as well as to remove those practices that prevent it in order to progress. Liberals think that current social facts are the product of earlier facts. Natural laws deny, refute, and kill anything that does not agree with them. If one desires to defeat nature, he should obey the natural law, rather than fighting against it. This is where socialists criticize liberals on the grounds that obeying the law of inequality is nothing but agreeing to preserve the prevailing inequality and injustice. If equality is a law, change and transformation are other laws. In this sense, development must be interpreted as "going always towards revolution" (Müsahabe-i iç̧timaiye [Sosyalizm Nedir], 1325, pp. 9-10). The liberals' interpretation of natural laws as somehow infinite and unchangeable is a principal delusion. Socialists perceive the laws of nature as continuous change. Consequently, the supporters of liberalism consider society as a planet suspended in an infinite constant balance. On the other hand, socialists liken the society to living organisms that are continually subjected to change since the day they are born and consider the economy to be the basic determinant of social change. For this reason, legal arrangements, as well as political, scientific, and ethical qualifications, are elements that affect social change. If people are to handle their jobs, they must first, be fed well. As society can only change as a whole, reform and revolution are necessary (Bedik, 1326, pp. 86-87).

Socialists obviously stress the law of change and seem to support revolution in an attempt to invoke sudden change, unlike liberals, who defended a progressive and selective transformation. The auther of "The Future of Socialism," published in Iştirak, stated that socialism 
can be realized through a strong rebellion and revolution. "As no change has ever been possible without shedding blood, it is no doubt that now and in the future any important change will be achieved by spilling blood and killing" (Musahabe-i lçtimaiye (Sosyalistliğin Atisi), 1326, p. 77) In other words, socialists will support revolution if it is an inevitable stage on the way to reaching the desired target. They do not want blood, but are aware that most of the disasters that erode humanity can be overcome only by shedding it. The means of production cannot restored to the public by progressive development, for a advocating progression is nothing but languor. The outcome is obvious: Man's own power that will bring about development. "Revolution is a great disaster, but a necessary and a temporary one." (Musahabe-i İçtimaiye (Sosyalistliğin Atisi), 1326, p. 77) This temporary disaster is a solution to the continuous disaster of progression. In general, socialists favor the French Revolution and, at the same time, view the Second Constitutionalism as an important milestone. All Ottoman socialists cannot expressly call for revolution. However, those who present a softer discourse justify this by the fact that the working class and its organization in the late Ottoman Empire were not sufficiently developed yet to undertake such a project. Sami points out that the Ottoman realm was in need of several reforms, among them public educationas well as urban and rural public improvements. He wrote that in such an atmosphere, one cannot make a revolution by suddenly destroying the existing structures. In other words, a long discussion period is needed, after which the society's level of understanding will be improved, and concepts like personality, honor, labor, pay, and others will be understood (Sami, 1326, pp. 2-3).

In line with the above-mentioned attitude, the Ottoman socialists, unlike the liberals, regard egalitarian approaches and movements in a positive light. For them, people do not represent a misguided and oppressive realm of conservatism, but rather the source of the dynamics needed to move forward. Thus, they interpret the concept of proletariat in the widest possible sense and try to reach the widest degree of mass support possible. Hasan Riza defines a socialist as one who commits oneself to revolt due to the widespread inequality and injustice in society. According to him, one cannot completely understand socialism by just reading books or engaging in theoretical discussions. In order to understand this profession, one has to move among the working people, live with them, and try to earn living just as they do. Even if somebody who does not lead such a life regularly attends labor union and worker association meetings and events, he will notice that he is in a different social domain, and may produce new opinions.

Ethem Nejat states that thoughts that place the individual at the center have an exaggerated trust in the individual and believe that one can succeed on his own against all economic and social organizations. Such views cause them to oppose egalitarian thought everywhere. In fact, liberal thought has a conservative viewpoint. Although it is obvious that a common struggle must be work for equality in a world where everything is shaped on a social basis, they stress the individual and misguide humanity toward a reactionist path. Individualist thought attaches importance to education and conditions success upon -long-term education and progressive change. Even in countries like the United Kingdom and Germany, which have spent decades to arrive at their current status quo and that individualists offer as examples, tendencies toward sociality and equality are gaining power. At a time when such countries are abandoning such thoughts, it will be meaningless for 
Ottoman society to turn toward them. However, the institutions and principles produced by international capitalism are growing rapidly in Turkey and workers do not have as much time as the liberals presume (Ethem Nejat, 1975b, pp. 176-178, 181).

Ziynetullah Nuşirevan states that many historical thought systems and movements emerged to help humanity and underlines that the divide that emerged in the domain of thought during the 19th century was completely different. He claims that this was the first time in history that a socialist movement based on society, social property, and equality opposed those views that wanted to achieve the happiness of the individual (Nuşirevan, 1975, pp. 231-234). İsmail Faik states that in France, which had a long tradition of aristocratic rule, great people like Montesquieu and Volter developed the concept of sovereignty of the nation with the influence of the British experience, after which scientists like Rousseau spoke of demands to spread equality and justice for everybody one in the country. This eventually led to the French Revolution which made it possible, for the first time, to establish a relationship between national sovereignty and the ordinary people. In this new setting, it finally became possible for the first reactions and movements against voting based on wealth, for example, could be developed. Although this revolution did not result in any gains for the poor, it did help prepare a basis for the birth of the egalitarian ideas upon which socialism was developed (İsmail Faik, 1326, pp. 5-6).

Ottoman socialists tried to formulate a broader definition of the proletariat and, consequently, to include different social segments into it in order to acquire as much popular support as possible due to the weakness of the Ottoman working class. Ethem Nejat considered the proletariat as a class of people who work and dedicate their lives to working, and yet always suffer hardship cannot earn in proportion to their labor. Based upon this understanding, he classifies this class in six subcategories: worker proletariat, peasant proletariat, artisan proletariat, servant proletariat, intellectual proletariat, and "vagabond" proletariat. Therefore, according to him $95 \%$ of the Turkish population belongs to this class (1975a, pp. 79-83). Şefik Hüsnü, who opposed those thinkers who rely on the thesis that Turkey has no working class and that its workers are not enduring some type of capitalist exploitation, as well as those who support liberal movements that intend to spread the understanding of rights in society, states that definitions resulting from such approaches are problematic. In fact, he writes that "the term proletariat covers the entire class of people who do not have any inherited or acquired capital and income, make their living by spending intellectual or physical labor and are deprived of means of making a living at times when they are not able to work for any reason." (Şefik Hüsnü, 1975, p. 111) Likewise, Hasan Rıza asserts that lowwage factory workers, small merchants and tradesmen, small property and landowners, small farmers and all peasants constitute the proletariat class (Hasan Rıza, 1920, pp. 22-29).

While the Ottoman socialists hold a pro-development view of society, they emphasize the fact that development is a struggle against nature and accord much importance to its aspect of change. Therefore, development can be achieved only by struggling with the law of nature, not by submitting to it. And so they deny progressive development and selective leadership. The majority is seen not a means of pressure of conservatism, but as the driving force of progress. For this reason, socialists who praise the French Revolution and the Second Constitutionalism see popular sovereignty as a positive step. They think that society's movement toward equality cannot be realized spontaneously, and that securing wide popular support, even by revolution, is a method to follow to realize change. 


\section{Relationship between the Organization's Purposes and Democracy}

Ottoman socialists have a positive attitude toward political organizations, one that is consistent with their desire to rely upon egalitarianism and a populer support as much as possible. They evaluate democracy and parliamentary system in terms of the benefits they will bring to organization and notably to the party organization. Therefore, they refer to democracy not in terms of its philosophy, but in terms of the means that will be used to reach the target.

Hasan Riza mentions three fields of activity for the socialist movement: ensuring the international cooperation and common movement of workers, organizing the working class under a party to realize the desired reforms, and acquiring the means of production and exchange in a manner that suits socialism (i. e., converting capitalists-owned enterprises into communal enterprises). All such activities mandate the founding of socialist party. According to him, masses of people can manage the means of production without capitalists.

Let us assume that all present and future owners of capital and wealth gather at some part of the world. Again let us assume that many wealthy people who live by securities and income without working join them. All of them sail on a big ship which is enough to accommodate all of them and travel to the North Pole and spend a few winters time there, what kind of changes would occur all over the world? Two important outcomes: First, despite the wealth and income they have, they will be not be able to please their souls as they were accustomed to. Even though they will not die of starvation, they will lead the life of a guest. The second outcome is most important for us. The world and the human society will not stop working. Workers will go to their factories and deal with their works. Production will be continued, products will be sold, engineers will be found, and chiefs, directors will be elected from among workers and employees for the branches that are without a director or supervisor, and the work will go on. (Hasan Riza, 1920, pp. 45-46)

However, it cannot be said that at present the working class on its own can fulfill these obligations. To that end, it must be organized and trained, according to him, through a four-stage process; unionization, solidarity, administrative reform and international cooperation, and joint action. During the third stage, the socialists will concentrate their activities on having representatives at the city council, State Council, and Parliament.

(Socialists) are obliged to nominate socialist deputies to represent the working class, and have the determination to defend their legal presence based on the principle of popular sovereignty. (Hasan Rıza, 1920, pp. 69-70)

Activities carried out by socialist parties to reach the majority will be an important step to invoke political developments toward equality.

If at times of election a socialist declares candidateship, the labor organization works for the success of that socialist. He serves as a representative of the citizens who share his ideas. The workers' party assumes all moral responsibility required for the election of that candidate. These socialist deputies execute all actions consistent with political principles of socialism to propose and pass several draft laws in the parliament to satisfy the tangible and intangible needs of the workers, commons and ordinary people. Such articles will provide strength and power to the policy of the worker organization, and guarantee the satisfaction of the class. (Hasan Rıza, 1920, p. 70) 
Stating that this was a time when oppressive regimes would be swept away and replaced by legitimate ones, Hasan Riza emphasizes that the same events were taking place in Late Ottoman Empire and the workers were doing their best to support this struggle. But, as he states, this does not signal the end of the working class' duty, for it now has to struggle to implement a democratic system that will adopt laws to benefit the majority of the people. Part of this will involve turning the capitalist-owned capital and means of production over to the majority (Hasan Riza, 1920, pp. 34-35).

The misery and hunger found well-off countries with long-standing parliamentary systems cannot eliminate these realities because these systems do not return the right to the real owners. Regardless of much good it does in the fields of law and public works, it cannot prevent capitalists from employing workers arbitrarily or workers from demanding their rights. Whichever sides wins the inevitable conflict between the two sides, society as a whole loses. Strikes cause people to suffer from lethargy, halt production, impoverish workers no matter how wealthy the labor union is bloody conflicts will occur. Socialism produces solutions that prevent such undesirable events (Sami, 1326, [1910], p. 3). Osman Zeki states that social development forces the nation to leave its "childhood" behind, for it has now arrived at a stage to self-management. This transition is completed when the aristocrats' dominance in the government is ended but are allowed to retain their social status (e.g. the United Kingdom) or by stripping them of all their former privileges (e.g. France). These developments reveal the fact that society must govern the state. With the Second Constitutional Monarchy, the Ottoman State took an important step toward that aim. The most obvious reflection of this situation is the increase seen in number of political parties and associations expressing the people's expectations. Therefore, socialists must be organized and strive to defend the interests of workers and employees who constitute the majority of the people and will benefit from such rights and atmosphere (Osman Zeki, 1326, pp. 2-4).

Socialists, unlike liberals, do not have a negative opinion of parliaments. Their top priority is the possibility that Parliament, instead of being controlled by the majority, may become dependent upon the executive power or that the right to vote based on wealth may be transformed into an instrument of the capitalist class. In every country, legislative power is for more distinguished and superior than executive power in terms of national sovereignty. Whereas Parliament legitimizes executive power, executive power is responsible for executing the laws issued by Parliament ("Kuvve-i Teşriiye Kararından...", 1326, p. 162). But during the constitutionalist period executive tended to intervention into legislative power. İsmail Faik praises the concept of national sovereignty and its execution by a representative government. While, referring to the developments experienced after the French Revolution, he underlines the fact that the revolution introduced an election system based on wealth, and in a sense, restored an illegitimate administration (İsmail Faik, 1326, pp. 7-8).

Bedik states that the poor condition of the working class make union and alliance compulsory. Success can be achieved through organization, not through intellectuals. Granting rights and achieving equality play a determinant role in the emergence of superior trends intrinsic to human nature. Competition and conflict are inevitable, and the working class is destined to sweep away autocracy and thereby achive victory. For that reason, the efforts 
to expand the liberties made by those organizations that have become stronger due to mutual solidarity are essential. Bedik says, "Everybody should come to the field of battle armed with the intangible weapons of freedom." (1326, p. 101) It should be noted those who hold such opinion consider that expanding rights and liberties, democracy and organization, and becoming stronger in the inevitable struggle as necessary instruments.

In his "Social Income and Political Parties," published in the Kurtuluş, Vedat Nedim states that the proletariat has no choice but to organize for to reinforce its position in society, and as a consequence, alleges that establishing a party is needed in order to overthrow the capitalist system. According to him, the real purpose of establishing a party is not to achieve political rights, and the rights gained as a result of that struggle are no more than concessions that the capitalist system is compelled to vest. In fact its primary purpose is to achieve complete equality by eliminating class conflict.

With the nationalization of the means of production - which is only desired by socialist parties - i.e., relieving them from the possession of a class and declaring them as public property, classes will disappear together with their conflicts and wars, and only then everybody will take his share of the social income, and again only then equality will become a reality between people. It is a ridiculous lie to claim that people who live as a (capital slave) of the other due to the economic life are legally equal. It is this lie which held humanity back for long years, but the proletariat that uncovered the gilt and saw the tin under it are now fighting for their rights which they have been deprived off for years. The victory of labor and the people will be a new milestone in the history of humanity. (Vedat Nedim, 1975, p. 36)

Similarly, Sami states that social life is an organism just like man and that society is comprised of a shape (politics) and a spirit (the people's sustenance). Constitutionalism is a fashion for politics and constitutionalism is a requirement for the people's living. Constitutionalism established the civil servants' power and protects their rights. For this reason political constitutionalism is deficient, and the next goal will be to realize "economy of constitutionalism" (Sami, 1326, p. 3). A similar discourse can be seen in an article that addresses the purpose of Ahali Firkası (People's Party), which some people tried to establish within the framework of activities of grouping in Parliament after constitutionalism. The author of the article pointed out that while constitutionalism is an important keystone in understanding what human rights and liberties are, it cannot, on its own, protect and preserve rights and liberties. Therefore the rule of society's election and control must prevail in every area of national sovereignty, and the to be formed party will be the instrument of struggle for that cause (Hayat-ı Meşrutiyet, 1326, p. 106).

According to Jean Renard, it is now a generally recognized request that the poor and the rich, the capitalist and the worker, Marx and a peasant must be subject to the same rules and laws. If we agree with this, we must also agree that the same equality must exist in the economic sphere, for the primary purpose of democracy is to abolish any wealth based upon the inequality of people, and to unite all the classes. In the absence of economic equality, equality cannot be implemented in other areas. To follow the thought of liberty, one must first be a democrat and then a socialist (Renard, 1326, pp. 165-166).

Notably after the First World War, we can say that Ottoman socialists had a very critical discourse on democracy. This was largely due to the Party of Union and Progress' failure to 
satisfy the positive expectations from constitutionalism. Even though the socialists retained the ideal of raising consciousness via organization and using the democratic atmosphere to that end, they interpreted or strove to understand democracy in light of the then-prevailing conditions as a result of the events they experienced. Ethem Nejat (1975b), who describes democracy as a bright and deceptive word of the bourgeoisie, states that its sole function is to enable bourgeoisie to act with even greater freedom:

Those who have the courage and power to save the country must seek ways to save the proletariat from slavery. As the whole world has actually realized that the ideas of the bourgeoisie systems that intend to create a middle class and the promises of democracy that bids mercy to the poor are void and merely lies, it will be vain to make such an attempt in our country. We must spend our intellectual power, political energy and governmental influence on methods and systems that will relieve the proletariat of the economic yoke of the bourgeoisie mentioned above. (p. 181)

Therefore, socialist organizations must have one overriding purpose: to embark upon a joint struggle against capitalism in cooperation with international socialist organizations.

This approach may be exemplified by the Sadrettin Celal's work, "Bourgeois Democracy and Socialism", in which he stresses the fact that democracy and socialism were increasingly discussed as two contrasting concepts after the First World War. According to him, there is an explicit campaign of attack against socialists and the people are being misled. Defenders of democracy claim that democracy benefits society in general, without any differentiation among classes, whereas socialism benefits only the working class. The supporters of democracy see socialism as a reaction in that sense. Considering that democratic governments have been in power for a long time in countries like the United Kingdom and France, Celal states that one can determine to what extent the democratic system has achieved its self-proclaimed purposes. For example, it claims that it depends on national sovereignty and thus is a method of government in which the majority is dominant because of its right to vote. So determining how much of society has the right to vote will be a good measure. Celal states that only $27 \%$ of French citizens possess this right and that the lawmakers are, in fact, not the majority of the people but a minority. He also asserts that it is debatable as to what extent the said $27 \%$ can freely exercise this right. In democracies, public opinion which keeps the institutions under control is of utmost importance. Public opinion is determined by schools, religious institutions, works of art and literature, and the press-all of which are controlled by the capitalists.

Let us explain our opinion: in democratic countries, it is the people who have relative control and elects the government, and determines the course of the internal and external policy of the country; but in practice, elections are made by the men of government who are representatives of the capitalists. (Antel, 1921, p. 11)

Poor voters, confused by all kinds of promises and attractive improvement projects, have no other role than putting an envelope into a case. Celal states that the second principle of democracy, namely, that people are born free and equal and should be legally free and equal, is often ignored, for democracy, as it develops, actually increases such inequality. People are born unequal, live unequal and die unequal. Under these circumstances, the rich understand freedom to mean making their employees work like slaves and robbing them; for the poor, it means no more than to die or to live like a slave. Democracy even distorts 
the meaning of justice by reducing it to nothing more than showing respect and credit for, and rewarding, robbers and charging those starving people who steal bread due with theft and, declaring them a danger to society, throw them in prison.

Ahmet Cevat presented another socialist interpretation of the relationship among socialism, democracy, and the party in his "How Can Masses of Workers and Peasants Form a Party?" He informs about what kind of party system must be established in the new republic before it hold its first parliamentary elections. According to him, the People's Party (PP) agrees with those laborers who want to abolish the sultanate and the caliphate, close the madrasahs and medieval courts, institute equality in family and personal law, and protect the country from foreign capital. However, other elements prevent laborers from meeting under the PP's umbrella. For example, despite its revolutionary nature PP refrains from preventing rival classes to exploit laborers. PP is a also national bourgeois party, for it is not proactive when it comes to fighting the parasitic classes. Ahmet Cevat says "we hope that PP confirms the rights of the laborer masses and does not hinder their organization" and urge laborers to gather under the umbrella of a separate party. He remarks that the essential purpose of any organization of laborers is to "wipe the wolf species off the face of the earth" and that struggle will begin with ideas and be followed by cannons and rifles at the appropriate. He call for a the establishment of bi-party system, including the PP and a Workers' Party. These two parties must be organized individually, act jointly when it comes to achieving reforms, and fight together against opportunists and reaction. This is, in a sense, a call that only these two parties should be permitted in the political arena. In conclusion,

The Proletariat must be organized individually, must rise with the force of struggle, must struggle as it rises until it inevitably takes over the control as a ruling class, achieves the great social salvation, and makes its own revolution, no matter how much time it takes. (Toprak, 1980, p. 121)

\section{Conclusion}

The relationship between the social structure and the laws of nature occupies an important place in the opinions expressed by the UiiM, Prince Sabahaddin, and Teşebbüs-i Şahsi ve Adem-i Merkeziyet Cemiyeti. In this framework, the understanding that people depend upon physical conditions and that these conditions limit society constitutes the liberals' basic starting point. External factors drive differentiation and development. Social development enables progress by giving rise to inequality. The UiiM authors consider that one of the most important subsequent inequalities is the one between a distinguished group that represents the minority but has foresight and the majority, which is inclined to preserve the status quo. If progress is to be achieved, the elite must act independently of the majority population's pressure. The UilM's authors have a negative opinion of institutions like elections and the parliamentary system because they believe that man is innately bad and that the majority is inclined to prevent development. For justifiable reasons, they strongly oppose the thought of a public revolution and criticize the French Revolution, which bears such characteristics. They define democracy as the autocracy of the people and try to justify it by establishing a connection with social development stage. Based on this negative per- 
ception, they harshly criticize democratic practices in the West. Democracy, which emphasizes the idea of equality, goes beyond the laws of nature and, in fact, ends up creating a ruling class that depends upon money and restricts the freedom of farsighted intellectuals. However, it also causes the lower social classes to move toward socialism for the sake of equality. In this sense, it prepares its own end. According to them, it is realistic to expect politics to become a profession, parallel to the development of social science, and until that day to create a government in which the farsighted elite will have the initiative to carry out a progressive transformation.

The Ottoman liberal Prince Sabahaddin voices a line of thought of development that gives rise to inequality but also introduces progress. However, his conclusions are significantly different from those of the Uiim group. The basic factor that prevents progress is not society's conservative trends, but oppressive regimes. As people are introduced to the instruments that will bring about progress, they will defend their freedom and, in contrast to the above- mentioned approach, become the driving force of progress. For this reason, the elite does not need to be protected from the people's pressure; rather, it should turn toward society and form a substructure via a widespread organization. A supporter revolution, he insistently emphasizes the need to create an organization that will overthrow an oppressive regime by one that will permit progress, instead of progressive change. When confronted with the fact (with which he agrees) that a parliamentary-dependent democracy can give rise to negative consequences, according to the nature of the society, the prince states that Parliament should not be restricted because it, along with election, is an indispensable institution. As these two factors cannot give rise on their own to democracy, they can be transformed into instruments to be used by a centralist, oppressive regime or may enable to majority to form an autocracy. Thus democracy may improve in real terms if the parliamentary system is supported by a decentralized management system. A democracy that permits progress may become a reality if management is expanded to include society via local governments and local councils and introduces supportive reforms in law and education. Thus, Sabahaddin rather suggests that the people will embrace a decentralized reform cooperatively realized by the central and local elites, instead of anything devised by a distinguished farsighted class. Organization is an important instrument in this sense; the primary goal must be to establish a decentralized democracy.

Ottoman socialists consider society a living organism and hold the idea of a development based on conflict and inequality. But they interpret development as progress toward equality, which is based on man's victory over natural laws. They therefore support any struggle and revolution initiated to defeat natural laws and the idea of a progressive change, which depends upon adapting to natural laws. Similar to Sabahaddin they view the majority as the driving force of development and thus have a positive attitude toward organization and popular participation in representative bodies at every level. While Sabahaddin's main goal is to institutionalize a decentralized democracy, socialists see democratic rights as a means for the working class to strengthen itself so that it can emerge victorious after the final struggle. In line with this, they comprehend and interpret the relationship between the working class party and democracy in accord with the circumstances of the period. For example, their positive attitude of the parliamentary system and democracy after the Second Constitutional Monarchy drove their attempt to interpret concepts associated with 
democracy, such as the freedom of organization, representation in Parliament, and state law, bearing in mind class conflict. The conflicts with the Party of Union and Progress led to a very critical approach to democracy. With the advent of the Republic, those Ottoman socialists who cooperate with Ankara emphasized the discourse of transitioning to socialism under the leadership of the People's Party. Tendencies supporting the establishment of two parties, one bourgeois and the other socialist, under the patronage of the People's Party, or supporting a forcible change under the management of the single party were seen; however, the expectation of transitioning to socialism were not fulfilled.

\section{References}

Ahmet Şuayb, Rıza Tevfik, Mehmet Cavid (15 Kanun-u Evvel 1325). "Mukaddime ve Program", Ulûm-u İktisadiye ve Içtimaiye Mecmuası, C. 1, S. 1: 1-10.

Ahmet Şuayb, (15 Kanun-u Evvel 1324) "Devlet ve Cemiyet" Ulum-u Iiktisadiye ve Içtimaiye Mecmuası, C.1, S.1: 54-71.

Ahmet Şuayb (1 Temmuz 1325). "Avalim-i İçtimaiye", Ulûm-u İktisadiye ve lçtimaiye Mecmuası, C. 2, S. 7: 289-331.

Akşin, Sina (1972). "31 Mart Olayına Değin Sabahattin Bey ve Ahrar Fırkası”, Ankara Üniversitesi Siyasal Bilgiler Fakülte Dergisi, C. 27: 541-560.

Alkan, Haluk - Doğan, Atila (Kış-Bahar 2010). "Osmanlı Liberallerinde Toplum ve Demokrasi Anlayışı”, Liberal Düşünce, Y. 15, S. 57-58: 69-93.

Alkan, Mehmet Ö.(2007). Prens Sabahaddin (Gönüllü Sürgünden Zorunlu Sürgüne Bütün Eserleri), İstanbul: Yapı Kredi Yayınları.

Alkan, Mehmet Ö. (Eylül 1990). "Bir İttihat ve Terakki Muhalifi Olarak Liberal Sosyalist Hilmi” Tarih ve Toplum, C. 11, S. 81: 47-51.

Altın, Hamza (Summer 2008). “Ethem Nejat ve Eğitim Tarihimizdeki Yeri”, Turkish Studies, Volume 3/4: 73-96.

[Antel] (1337; 1921). Burjuva Demokrasisi ve Sosyalizm, İstanbul: Evkâf-ı İslâmiye Matbaası.

Asaf Nefi (1 Ağustos 1325). "Mücadele-i Hayatiye ve Tekamül-ü Cemiyet", Ulum-u İktisadiye ve lçtimaiye Mecmuası, C. 2, S. 8: 455-480.

Bakırezer, Güven (2005). "Türkiye'de Sosyal Liberalizm”, Modern Türkiye'de Siyasi Düşünce, Liberalizm, Edt., T. Bora- M. Gültekingil, İstanbul: Iletişim Yayınları, C. 7: 139-163.

Bedi Nuri (1 Temmuz 1325). "Kabiliyat-i İçtimaiye", Ulum-u Iktisadiye ve lçtimaiye Mecmuası, C. 2, S. 7: 322-353.

Bedik (20 Mart 1326). "Sosyalist Mektebi", İstirak, Sene 1, S. 6: 86-88.

Bedik (27 Mart 1326). “Cereyan-ı Cedid”, İştirak, Sene 1, S. 1: 97-101.

Belge, Murat (2008). "Türkiye'de Sosyalizm Tarihinin Ana Çizgileri”, Modern Türkiye'de Siyasi Düşünce, Sol, Edt., T. Bora-M. Gültenkingil, İstanbul: İletişim Yayınları, C. 8: 19-48.

Benlisoy, Foti ve Çetinkaya,Y. Doğan (2008). "Işstirakçi Hilmi", Modern Türkiye'de Siyasi Düşünce, Sol, Edt., T. Bora-M. Gültenkingil, İstanbul: Illetişim Yayınları, C. 8: 165-183.

Çavdar, Tevfik (1992). Türkiye'de Liberalizm (1860-1990), Ankara: İmge Yayınları.

Demir, Murat Seyrek (Fall 2010). "The Roots of Turkish Civil Society: The Ottoman Period", Turkish Studies, Volume 5/4: 1421-1441.

Doğan, Atila, (2005). "Ulum-u İktisadiye ve İçtimaiye Mecmuası'nda Liberal Anlayış", Modern Türkiye'de Siyasi Düşünce, Liberalizm, İstanbul: İletişim Yayınları, C. 7: 75-83.

Doğan, Necmettin (2006). The Origins of Liberalism and Islamism in the Ottoman Empire (1908-1914), Doctorate for getting philosophy doctorate degree at Berlin Freedom University/ Faculty of Political and Social Sciences /Sociology Institute

Ethem Nejat (1975). “Proletarya Kimlerdir", Kurtuluş, İstanbul: Anadolu Yayınları: 75-83.

Ethem Nejat (1975). "Sosyalizm ve Ferdiyetçiler", Kurtuluş, İstanbul: Anadolu Yayınları. 176-182. 
Ferda (Uzun Bir Konferanstan) (27 Şubat 1325). İştirak, Sene 1, S. 3: 33-36.

Gürel, Burak ve Nacar, Can (2008). “Şefik Hüsnü (Değmer), Modern Türkiye'de Siyasi Düşünce, Sol, Edt., T. Bora-M. Gültenkingil, İstanbul: İletişim Yayınları, C. 8: 118-137.

Güzel, Cemal (2008). "Türkiye'de Maddecilik ile Maddecilik Karşıtı Görüşler", Modern Türkiye'de Siyasi Düşünce, Sol, Edt., T. Bora-M. Gültenkingil, İstanbul: İletişim Yayınları, C. 8: 49-67

Hanioglu, M. Sükrü (2001). Preparation for a Revolution The Young Turks, 1902-1908, New York: Oxford University Press.

Hasan Rıza (1920). Sosyalizm, İstanbul: Evkâf-ı İslamiye Matbaası.

Helvacı, Pelin (2007). Prince Sabahattin (1878-1948) and his Place in Ottoman Intellectual Development, Master of Arts, Atatürk Institute for Modern Turkish History, Boğaziçi University.

İsmail Faik (5 Ağustos 1326). "Sosyalizm Efkarı-1-", Insaniyet, Sene 1, S. 1: 4-8.

Karaman, Deniz (Mayıs 2004). "Ulûm-ı İktisadiye ve İçtimaiye Mecmuası", Cumhuriyet Üniversitesi. Sosyal Bilimler Dergisi, C. 28, N. 1:65-87.

Osman Zeki (5 Ağustos 1326). "Insaniyet", Insaniyet, Sene 1, S. 1: 2-4.

Renard, Jean (24 Nisan 1326). "istikbal Sözleri”, Iştirak, Sene 1, S. 11: 163-166.

Rıza Tevfik (1 Haziran 1325). "Hürriyet, İngiliz Hekim-i Meşhuru John Stuart Mill Hürriyeti Nasıl Anlıyor," Ulum-u iktisadiye ve lçtimaiye Mecmuası, C. 2, S 6: 190-237.

Rıza Tevfik (1 Şubat 1325). "Hükûmet ve Hürriyet Hakkında Spencer'ın Felsefesi", Ulûm-u İktisadiye ve Iç̧timaiye Mecmuası, C. 1, S. 14-2: 233-245.

Rıza Tevfik (1 Nisan 1326). "Hukuk-u Esasiyeye Medhal", Ulum-u iktisadiye ve Içtimaiye Mecmuası, Sene iki, C. 1, S. 16: 532-576.

Rıza Tevfik1 (Mayıs 1326). "Hukuk-u Esasiyeye Medhal", Ulûm-u İktisadiye ve lçtimaiye Mecmuası, C. 1, S. 17: 613-629.

Rıza Tevfik (Haziran/Eylül 1326). "Hükûmet ve Hürriyet Hakkında Spencer'ın Felsefesi", Ulûm-u Iktisadiye ve içtimaiye Mecmuası, cilt 2, Sayı 18-21/6-9: 742-757.

Sami (11 Teşrin-i Sani 1326). "Millet Sosyalistleri Sevmelidir", Sosyalist, Sene 1, S. 1: 2-3.

Şefik Hüsnü (1975). “Yarınki Proletarya”, Kurtuluş, İstanbul: Anadolu Yayınları. 109-116.

Tunaya, Tarık Zafer (1984). Türkiye'de Siyasi Partiler, (ikinci Meşrutiyet Dönemi 1908-1918) Cilt 1, İstanbul: Hürriyet Vakfı Yayınları.

Tunaya, Tarık Zafer (1986). Türkiye'de Siyasal Partiler(Mütareke Dönemi 1918-1922), II Cilt, Istanbul: Hürriyet Vakfı Yayınları.

Tunçay, Mete (1978), Türkiye'de Sol Akımlar (1908-1925), Bilgi Yayınları.

Tunçay, Mete - Zürcher, Erik Jan (2010). Osmanlı Imparatorluğu'nda Sosyalizm ve milliyetçilik (1876-1923), İstanbul: İletişim Yayınları.

Ülken, Hilmi Ziya (1992). Türkiye'de Çağdaş Düşünce Tarihi, İstanbul: Ülken Yayınları.

Vahan Vasfi (25 Teşrin-i Sani 1326). "Sosyalizm Nedir", Insaniyet, Sene 1, S. 3: 3-4.

Vedat Nedim (1975). "Toplum Geliri ve Siyasi Partiler", Kurtuluş, İstanbul: Anadolu Yayınları. 31-36.

Ziynetullah Nuşirevan (1975). "(Türkiye ve Sosyalizm) Meselesi Üzerine Bazı Mütalaalar", Kurtuluş, İstanbul: Anadolu Yayınları. 231-237.

(27 Mart 1326) “Hayat-ı Meşrutiyet (Ahali Fırkası)", Işstirak, sene 1, S. 1: 106-107.

(13 Şubat 1325). "Müsahabe-i İçtimaiye, (Sosyalizm Nedir)", Iştirak, sene 1, S. 1: 8-12.

(27 Şubat 1325). “Musahabe-i iç̧timaiye (Sosyalistliğin Atisi)”, Iştirak, Sene 1, S. 3: 36-41.

(24 Nisan 1326). "Kuvve-i Teşriiye Kararından Rucu Ediyor (Damatlar Maaş)", Işstirak, Sene 1, S. 11: 162. 
